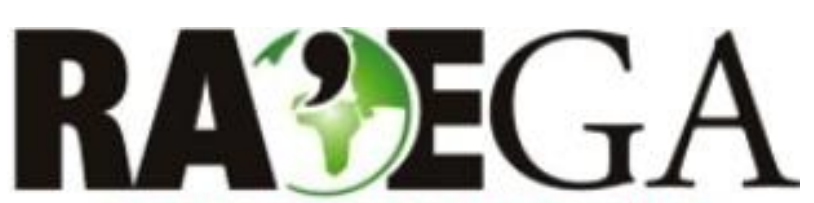

O ESPACYO GEOGRÁFICO EM ANÁLISE

\title{
REDES DE TRANSPORTES E COMÉRCIO INTERNACIONAL: os fluxOS das exportações do setor siderúrgico-metalúrgico no norte de Minas Gerais
}

\section{TRANSPORT NETWORKS AND INTERNATIONAL TRADE: the flows of exports of the steel and metallurgical industry in north of Minas Gerais}

\author{
Luiz Andrei Gonçalves Pereira \\ Doutorando em Geografia - Instituto de \\ Geografia/UFU \\ Bolsista da CAPES \\ Uberlândia, MG, Brasil \\ e-mail: luizandreigoncalves@yahoo.com.br \\ William Rodrigues Ferreira \\ Professor Associado do Instituto de Geografia - UFU \\ Uberlândia, MG, Brasil \\ e-mail: wferreira@ufu.br
}

\section{Artigo recebido em: 31/10/2012.}

Artigo aceito em: 11/11/2013.

\section{Resumo}

O sistema de trocas de bens e de serviços no comércio internacional tornou-se mais complexo e articulado, em um processo de interação espacial que ocorre a partir da organização das redes de transportes, das comunicações e dos fluxos de capital no espaço geográfico. O objetivo deste trabalho é analisar a configuração espacial das redes de transportes responsáveis pelo escoamento das exportações do setor siderúrgico-metalúrgico destinadas ao mercado internacional, enfocando a região norte de Minas Gerais, no período entre 2004 e 2011. As mercadorias exportadas foram transportadas exclusivamente por transporte rodoviário no percurso nacional; consequentemente, os portos, aeroportos e pontos de fronteiras articulados ao transporte marítimo, aéreo e rodoviário internacional viabilizaram os fluxos das exportações.

Palavras-chave: Redes de transportes; comércio internacional; exportações; setor siderúrgico-metalúrgico. 


\begin{abstract}
The system of trade in goods and services in international trade has become more complex and articulated in a process of spatial interaction, which occurs from the organization of transport networks, communications and capital flows in geographic space. The aim of this paper is to analyze the spatial configuration of transport networks responsible for the flow of exports of steel and metallurgical industry for the international market, focusing on the northern region of Minas Gerais, in the period 2004 to 2011. The exported goods were transported exclusively by truck on national route, therefore, ports, airports and border points articulated maritime transport, international road and air flows of exports made possible.
\end{abstract}

Keywords: Transport networks; international trade; exports; steel and metallurgical industry.

\title{
INTRODUÇÃO
}

O sistema de trocas de bens e de serviços no comércio internacional tornouse mais complexo e articulado, em um processo de interação espacial que ocorre a partir da organização das redes de transportes, de comunicações e de fluxos de capital no espaço geográfico. A localização concentrada ou dispersa das fontes de matéria-prima, das fontes de energia, das plantas industriais, das empresas prestadoras de serviços e dos mercados consumidores em diversas regiões do mundo passou a requerer um sistema de transporte internacional eficaz e eficiente para otimizar os fluxos das trocas comerciais entre as economias dos países desenvolvidos, em desenvolvimento e subdesenvolvidos. Os diversos países envolvidos nas relações econômicas internacionais tornaram-se dependentes das articulações simultâneas das redes modernas de transportes e de comunicações capazes de promover, de forma mais rápida, segura e com baixo custo, os fluxos de capital no cenário internacional.

Nesse contexto, este trabalho busca responder à seguinte questão: como estão organizadas as redes de transportes que inseriram os fluxos das exportações do setor siderúrgico-metalúrgico do norte de Minas Gerais no comércio internacional? O objetivo é analisar a configuração espacial das redes de transportes 
responsáveis pelo escoamento das exportações do setor siderúrgico-metalúrgico destinadas ao mercado internacional, enfocando a região norte de Minas Gerais, no período entre 2004 e 2011.

No processo de desenvolvimento da pesquisa que originou este artigo, os estudos concentraram-se na revisão da literatura e na coleta de dados disponibilizados pelas instituições governamentais, como o Departamento de Estradas de Rodagens de Minas Gerais - DER/MG - e o Ministério do Desenvolvimento, Indústria e Comércio Exterior - MDIC/ALICEWEB2. A parte empírica da pesquisa foi desenvolvida através da coleta de dados nas fontes primárias, por meio da aplicação de dez entrevistas semiestruturadas a representantes do setor de logística ou de comércio exterior das empresas exportadoras do setor siderúrgico-metalúrgico, com domicílios fiscais nos municípios do norte de Minas Gerais. As informações extraídas das entrevistas permitiram identificar as redes de transportes utilizadas pelas empresas exportadoras, apontar problemas do sistema de transportes e propor possíveis soluções para esses problemas, visando a melhorias constantes nas redes de transportes que escoam as exportações da região norte-mineira.

\section{Redes de transportes e organização espacial}

Na ciência geográfica, o que são as redes de transportes? Para Rodrigue, Comtois e Slack (2006), a rede de transportes é uma referência ao quadro de rotas de um sistema de localizações identificado como nós, uma vez que a rota constitui uma ligação entre dois nós, que são parte de uma grande rota, referindo-se às rotas mais tangíveis, como estradas e trilhos, ou a rotas menos tangíveis, como corredores aéreos e marítimos. As redes de transportes estão incluídas em uma estrutura espacial composta pela organização da infraestrutura viária e dos terminais de transportes que viabilizam as relações entre a origem e o destino dos fluxos de cargas e de passageiros no espaço geográfico.

As redes de transportes são constituídas por um sistema arterial de organização espacial por meio de rotas viárias que articulam os arcos e os nós na estrutura da rede, tornando-se um foco de atração, de geração e de distribuição dos 
fluxos que, consequentemente, viabilizam a circulação de pessoas, de bens e de serviços pelas redes (PONS; BEY, 1991. PONS; REYNÉS, 2004). É importante frisar que os elementos infraestruturais básicos das redes de transportes são as ligações e os nós das conexões responsáveis pela organização dos fluxos no espaço geográfico.

Nas redes de transportes, as ligações são as próprias instalações viárias, como as hidrovias, as rodovias, as ferrovias e as vias aéreas, enquanto os nós são representados por cidades ou por terminais de cargas e/ou passageiros que são interconectados por um determinado conjunto de ligações. Estas ligações e os nós promovem acessibilidade aos lugares e também viabilizam os fluxos de veículos, de passageiros e de mercadorias que circulam constantemente ou em determinado período nos sistemas de transportes (TAAFFE; GAUTHIER; O`KELLY, 1996). As ligações, a acessibilidade aos nós e os fluxos nas redes de transportes promovem as interações espaciais, estruturando as articulações do espaço geográfico local, regional, nacional e internacional.

Considerando os fluxos nas redes de transportes, Corrêa (2006, p. 279) destaca que:

As interações espaciais constituem um amplo e complexo conjunto de deslocamentos de pessoas, mercadorias, capital e informação sobre o espaço geográfico. Podem apresentar maior ou menor intensidade, variar segundo a frequência de ocorrência e, conforme a distância e direção, caracterizar-se por diversos propósitos e se realizar através de diversos meios e velocidades.

Nas redes de transportes, a amplitude e a complexidade das interações espaciais dos fluxos de bens e de serviços são caracterizadas por variações na intensidade, na frequência e na velocidade dos meios de transportes para transpor/superar as distâncias no espaço geográfico. Dentro das redes de transportes, cada modalidade forma ou tem a sua própria rede, sendo caracterizada, de forma segmentada, como rede rodoviária, ferroviária, marítima, aeroviária, hidroviária ou dutoviária. No processo de conexão de duas ou mais modalidades de transportes, tem-se constituída a complexa rede de transporte intermodal, que é muito utilizada no 
transporte internacional de cargas no cenário mundial. Diante dessa complexa rede, na sequência, será discutido o papel das redes de transportes nos fluxos de mercadorias no comércio internacional.

\section{COMÉRCIO INTERNACIONAL: redes de transportes e fluxos internacionais de mercadorias}

O comércio internacional é definido pelo sistema de trocas que ultrapassa as fronteiras nacionais dos países, sendo representado por duas vias: uma, das vendas, que são as exportações; e a outra, das compras, que são as importações (MAIA, 2004). No contexto das trocas de bens e de serviços na escala local/regional à internacional, ou vice-versa, Arroyo (2012, p. 8) aponta que "os fluxos internacionais de mercadorias expressos nas exportações e importações mostram as relações que distintas frações do território nacional têm com o mundo através da atividade mercantil". A espacialidade dos processos econômicos, representada pelos fluxos que ultrapassam as fronteiras nacionais, resulta na aceleração da circulação do comércio mundial, em um contexto de estratégias empresariais que desenvolvem e/ou desenham novas tramas de negócios a partir das interações entre as empresas e os mercados localizados em diferentes países desenvolvidos e em desenvolvimento (ARROYO, 1995).

Para explicar os princípios das trocas no comércio internacional, Rodrigue, Comtois e Slack (2006) destacam que, na economia mundial, nenhum país é autossuficiente em produção para abastecer o seu mercado interno, tornando-se necessárias as trocas de bens e de serviços entre os países envolvidos nas relações econômicas internacionais. Sendo assim, cada país está envolvido em diferentes níveis de comércio internacional, para vender o que produz para o exterior e também para adquirir, no mercado externo, o que não é produzido no seu mercado interno, constituindo uma flexível e complexa rede de trocas comerciais no espaço geográfico mundial. Consequentemente, o sistema de compra e de venda está se inter-relacionando constantemente no mercado internacional.

A ascensão do comércio internacional no período Pós-Segunda Guerra Mundial tem aumentado a interdependência dos diversos elementos componentes 
da economia mundial, que são constituídos de numerosos relacionamentos espaciais contínuos e descontínuos nos fluxos de capitais, de mercadorias, de matérias-primas, de serviços e de informações entre as diferentes regiões do mundo. Para Rodrigue, Comtois e Slack (2006), o comércio internacional de bens e de serviços foi facilitado principalmente devido à aplicação de recursos tecnológicos na integração produtiva, à eficiência dos meios de transportes e de comunicações e à flexibilidade das transações financeiras. A junção desses elementos contribuiu para a redução dos custos de produção e de circulação, viabilizando os fluxos de capital e de consumo, principalmente em pontos estratégicos dos territórios internacionais.

Na concepção de Monié (2011), o grande crescimento das trocas comerciais imprimiu à infraestrutura logística uma função estratégica de articular interna e internacionalmente os espaços de produção e de consumo. Isso ocorreu de duas formas: na primeira, os diversos países e as regiões participam dos fluxos econômicos globais, com maior dispersão dos fornecedores, produtores e consumidores, que passaram a exigir uma maior capilaridade dos sistemas de transportes. Na segunda forma, a organização da produção e dos fluxos em redes também exige uma conexão perfeita entre os nós e os vetores, uma vez que qualquer problema na rede compromete os fluxos.

Para Rodrigue (1999), o processo de globalização econômica dos mercados internacionais tem recebido apoio para melhorias constantes na tecnologia de transportes e também em investimentos na infraestrutura de transporte para a superação de maiores distâncias em menor espaço de tempo. O desenvolvimento das redes de transportes nacionais e internacionais ampliou o aproveitamento prolongado das vantagens comparativas, em termos de recursos, de capital e de trabalho, em diferentes mercados mundiais. Sendo assim, o crescimento dos fluxos de mercadorias, a redução dos custos de produção e a disponibilização de mais produtos nos mercados, por conseguinte, aumentou também o consumo, a produção e a circulação em escala internacional.

A modernização tecnológica das redes de transportes possibilitou 0 crescimento dos fluxos nos sistemas de distribuição de mercadorias, aumentando os deslocamentos de bens e de serviços no espaço geográfico, em tempo 
relativamente menor. Rodrigue (1999) destaca que os movimentos das mercadorias não estão ocorrendo muito mais rápido, mas se tornaram mais eficientes e rentáveis. Isto porque a velocidade dos aviões (Boeing) é praticamente a mesma de 25 anos atrás. No caso do fluxo marítimo, a velocidade também não tem melhorado significativamente nos últimos 50 anos. $O$ crescimento do comércio internacional não pode estar ligado somente às melhorias da velocidade modal de transportes, está relacionado também à maior capacidade dos veículos de transportar cada vez mais quantidades de mercadorias com menores custos operacionais. Além disso, a redução do tempo de transbordo nos terminais de cargas melhorou consideravelmente a capacidade e a eficiência dos sistemas de transportes.

A difusão das redes de comunicações (telefonia e internet) no cenário internacional tem aumentado também os fluxos de capital, as atividades comerciais e as necessidades por transportes. As melhorias dos sistemas de transportes ocorreram, em sua maioria, nos terminais de cargas, por meio do sistema de sincronização, que viabilizou mais rapidamente a continuidade dos fluxos e a integração dos sistemas de transportes. Para Rodrigue (1999), a sincronização dos terminais de cargas otimizou os fluxos nas redes de transportes, principalmente no recebimento, no transbordo e na distribuição dos fluxos de mercadorias, garantido, assim, a continuidade e a rapidez nos fluxos, uma vez que não é possível aumentar significativamente a velocidade dos meios de transportes. Dessa forma, a sincronização diminuiu o tempo de espera e aumentou a rapidez nos transbordos das cargas de um modal de transporte para outro. Isso só foi possível por meio das melhorias significativas das redes de comunicações (telefone e internet), que contribuíram com a agilização do processo de sincronização nos terminais de cargas.

A constante articulação da prestação de serviços dos terminais de transportes e suas modalidades possibilitou os fluxos ininterruptos de mercadorias para o funcionamento do modelo de consumo e de produção pós-fordista. Monié (2003, p. 60) explicita a interação entre esses fatores na afirmação que se segue:

A noção de circulação torna-se uma questão central desse modelo pós-fordista que vende a mercadoria antes de sua produção e impõe 
uma reorganização completa dos sistemas de transportes nos seus aspectos infraestruturais, institucionais, gerenciais e operacionais.

O sistema de sincronização dos terminais de cargas e dos meios de transportes trabalha com fluxos contínuos, com baixo ou nenhum estoque de mercadorias, pautado no sistema de just in time de produção, uma vez que os serviços de transportes e de comunicações mantêm as cargas em constante circulação no espaço geográfico. Todavia, uma interrupção no fluxo - por condições do tempo, quebra de veículos, greves, acidentes, entre outros - afeta toda a cadeia de circulação na rede de transportes que, por exemplo, pode parar temporariamente as atividades produtivas e comerciais. Em países como, mais especificamente, o Brasil, que apresenta sérios problemas na infraestrutura de operacionalização das redes de transportes, os fluxos podem sofrer ainda interrupções mais constantes.

Os problemas na infraestrutura dos transportes brasileiros têm elevado os custos de produção e de circulação, o que os empresários, os governantes e os pesquisadores denominam de custo Brasil. Nas palavras de Monié (2003), o custo Brasil é caracterizado pelos conjuntos de gargalos estruturais, institucionais e operacionais da infraestrutura de logística e de transporte; resultam na elevação dos custos de produção e, consequentemente, afetam a capacidade de competitividade frente à concorrência internacional, onerando principalmente os setores exportadores do país. O custo Brasil reintroduziu o debate sobre a necessidade de retomar urgentemente os investimentos na infraestrutura, reatualizando, reestruturando e modernizando os setores de transportes.

As melhores condições da infraestrutura de circulação, de produção e de consumo estão mais concentradas e organizadas nos chamados países desenvolvidos. Coforme Pons e Reynés (2004) e Rodrigue, Comtois e Slack (2006), a configuração da geografia do comércio internacional ainda revela o predomínio de um pequeno número de países, principalmente na América do Norte, na Europa e na Ásia, formando uma tríade constituída pelos Estados Unidos, pela Alemanha e pelo Japão, que dominam cerca de um terço de todo o comércio global. Mas essa supremacia está sendo desafiada pelas economias emergentes.

$\mathrm{Na}$ atualidade, realmente, ocorre a ampliação do comércio internacional entre os países emergentes, principalmente China, Brasil e Índia, entre outros. No setor de 
transportes, Laxe (2005) frisou o crescimento na prestação de serviços de transportes internacionais das companhias marítimas asiáticas de países emergentes, como China, Hong Kong (China), Coréia do Sul, Singapura, Taiwan e Malásia, que têm se destacado e ampliado a sua participação no escoamento de bens e de serviços no cenário internacional.

A prestação dos serviços de transportes das companhias localizadas em países desenvolvidos, emergentes e subdesenvolvidos no comércio internacional é de suma importância para o funcionamento das atividades econômicas, principalmente na viabilização dos fluxos de bens e de serviços. Para Rodrigue, Comtois e Slack (2006), aproximadamente metade de todo o comércio mundial ocorre entre as localidades com distâncias que ultrapassam 3.000 quilômetros. Esse é um dos motivos que leva ao envolvimento de vários modos integrados de transportes nos movimentos dos fluxos internacionais. Por isso, nas redes de transportes internacionais, são necessárias estratégias que articulem, espacialmente, as modalidades de transportes e os terminais de cargas na economia mundial.

As relações espaciais no comércio internacional ocorrem por meio do transporte intermodal, podendo ser uma exceção somente nos países que possuem fronteiras e vias de acessos terrestres. Para Hoyle e Knowles (2001), o transporte intermodal é caracterizado pelo fluxo de carga que envolve uma interação espacial do remetente ao destinatário, no qual uma unidade de carga é transportada em, pelo menos, dois modos de transportes diferentes, com contrato único para transpor o espaço geográfico. A sua finalidade básica é fornecer um sistema de fluxo contínuo, em que as vantagens relativas de cada modo de transporte são combinadas para produzir, de forma mais eficiente e com menor custo, a prestação de serviços porta a porta nos deslocamentos de mercadorias, principalmente no comércio internacional.

$\mathrm{Na}$ política de exportação, as redes de transportes intermodais estão inseridas em uma estrutura espacial constituída por transporte nacional, que leva a mercadoria do local de produção até o terminal; terminais de cargas, que recebe e distribui as mercadorias; e transporte internacional, que leva a mercadoria do terminal nacional para outros terminais de cargas no exterior. As redes de 
transportes são constituídas por grupos de modalidades terrestres, aquaviárias e aeroviárias.

No Brasil, as redes de transportes terrestres nacionais são constituídas pelos modais rodoviário, ferroviário e dutoviário, que integram as atividades econômicas no espaço geográfico nacional, principalmente ligando as regiões costeiras e interioranas. Na política de exportação, utilizam-se, para levar as mercadorias do local de produção até os terminais de cargas alfandegados, portos, aeroportos e pontos de fronteiras. É importante destacar que parte dos fluxos rodoviário e ferroviário é destinada, em maior quantidade, aos portos, que são responsáveis pela distribuição de grande parte da mercadoria exportada no cenário internacional. A partir desses terminais, as mercadorias seguem para o exterior na modalidade marítima (predominante), aeroviária ou terrestre. O transporte internacional terrestre, rodoviário e ferroviário ocorre após os pontos de fronteiras, que estão localizados entre os países que possuem fronteiras terrestres.

Os terminais de cargas alfandegados estão localizados nas fronteiras aquaviárias (portos), aéreas (aeroportos) e terrestres (pontos de fronteiras), que recebem os fluxos de bens e de serviços produzidos nos mercados nacionais e destinados ao mercado internacional. A partir desses terminais alfandegados, há a ocorrência do transporte internacional para a distribuição dos fluxos de mercadorias no mercado mundial. No terminal portuário, encontra-se uma maior quantidade de empresas prestadoras de serviços de transportes mais especializados para viabilizar os fluxos na rede intermodal de transporte.

O transporte internacional ou de longa distância é caracterizado pelos fluxos das mercadorias que ocorrem a partir dos terminais alfandegados, por meio de transportes marítimos, aeroviários e terrestres. Para Rodrigue, Comtois e Slack (2006), os terminais portuários e os transportes marítimos são responsáveis por cerca de $90 \%$ dos fluxos em tonelagem, e aproximadamente $70 \%$ dos valores financeiros das mercadorias em circulação no comércio global, principalmente dos produtos de maior volume ou peso. O transporte aéreo internacional transporta cerca de $0,2 \%$ dos fluxos de cargas em tonelagem e mais ou menos $15 \%$ dos valores financeiros das mercadorias no mercado internacional. $O$ transporte 
aeroviário é responsável principalmente pelos deslocamentos dos produtos de baixo peso e volume; basicamente, os produtos tecnológicos e perecíveis.

No comércio internacional, a modalidade de transporte marítimo é de suma importância nos fluxos de bens e de serviços, pois os custos operacionais são menores, comparado aos outros modais de transportes. As interações espaciais dos transportes terrestres, da estrutura portuária e do transporte marítimo propiciaram o predomínio do transporte intermodal na cadeia de fluxos globais. Peyrelongue (1999) afirma que a intermodalidade procedeu das relações espaciais do transporte marítimo e dos portos, por intermédio da implementação do contêiner, uma grande invenção tecnológica que permitiu a integração das redes de transportes terrestres e marítimos, na organização e na intensificação dos fluxos de longa distância na cadeia produtiva mundial. Os contêineres revolucionaram as redes de transportes e demandaram navios maiores para o transporte de cargas, melhoramentos na infraestrutura portuária e especialização das empresas prestadoras de serviços de transportes, o que terminou por contribuir para a ampliação do comércio internacional (LAXE, 2005).

O crescimento dos fluxos por contêiner tem otimizado os custos logísticos, principalmente com a redução dos custos das embalagens e dos transbordos nos terminais de cargas, facilitando os fluxos de mercadorias através do transporte intermodal. Conforme Monié (2011, p. 307), "o uso do contêiner foi decisivo para diminuir os custos e para suavizar a gestão das interfaces intermodais". Para Rodrigue e Notteboom (2009) e Pons e Reynés (2004), o contêiner foi considerado mais do que uma caixa de aço, uma vez que é um vetor importante nas interações espaciais; revolucionou os meios de transportes, tendo impactos significativos na estrutura de produção, de distribuição e de consumo. A gestão dos fluxos de mercadorias por contêiner foi viabilizada pela atuação conjunta da rede de transportes e da rede telemática, que ampliou o tráfego em termos quantitativos, qualitativos e espaciais. No cenário econômico atual, um dos grandes desafios para o transporte em contêiner é a superação da circulação de contêineres vazios, que ocorre diante dos desequilíbrios comerciais no espaço geográfico.

Nas redes de comércio internacional, as interações espaciais das redes de transportes, de terminais de cargas (contêiner) e de comunicações estão cada vez 
mais flexíveis e complexas, principalmente nos relacionamentos do sistema de compra e venda que ampliaram os fluxos de bens e de serviços no mundo globalizado. Considerando esse contexto, a próxima seção demonstra como estão estruturadas e organizadas as redes de transportes que inseriram as exportações do setor siderúrgico-metalúrgico da região norte-mineira no cenário econômico internacional.

\section{NORTE DO ESTADO DE MINAS GERAIS: redes de transportes terrestres e organização espacial das empresas exportadoras do setor siderúrgico- metalúrgico}

A expansão dos meios de transportes terrestres propiciou o desenvolvimento do sistema capitalista nas áreas interioranas do território brasileiro. Nesse contexto, também favoreceu o crescimento das atividades produtivas e comerciais na mesorregião norte de Minas Gerais, ampliando as relações econômicas entre essa região e os demais mercados nacionais e internacionais. O processo de desenvolvimento dos sistemas de transportes terrestres no norte de Minas pode ser caracterizado por dois períodos históricos: antes e após a criação da Superintendência do Desenvolvimento do Nordeste - SUDENE.

O primeiro período foi o que antecedeu à implantação da SUDENE, caracterizado pela implementação do sistema ferroviário e das rodovias não pavimentadas, desenvolvendo o sistema viário e urbano, promovendo as interações espaciais na circulação de pessoas, no transporte de cargas e no surgimento dos entrepostos comerciais. Isso deu fôlego às atividades comerciais, principalmente em Montes Claros e Pirapora. O segundo período ocorreu após a criação da SUDENE, em 1959, instituição pública federal que subsidiou a implantação das políticas de desenvolvimento regional por meio de uma ação conjunta dessa instituição com os demais órgãos estaduais e prefeituras municipais, o que resultou em melhorias da infraestrutura e favoreceu o processo de modernização econômica, principalmente na região norte-mineira (PEREIRA, 2010).

A SUDENE, conforme estabelecido em seu segundo Plano Diretor (1963 1966), passou atuar no território norte-mineiro a partir de 1963, tornando-se um 
marco importante no processo de modernização da infraestrutura econômica de transporte rodoviário e ferroviário. Para Pereira (2010), as ações estatais subsidiaram, por meio de incentivos fiscais e financeiros, a expansão das atividades produtivas privadas, representadas pelas atividades pecuaristas, agrícolas, agroindustriais, industriais e de serviços. No setor de transportes terrestres, ocorreu o reaparelhamento das vias permanentes e do material rodante do sistema ferroviário, além da pavimentação de rodovias federais, estaduais e municipais no norte de Minas Gerais. Segundo Pereira e Lessa (2011), os investimentos nos setores de infraestrutura econômica e os subsídios estatais contribuíram para o processo de expansão do capital privado no norte de Minas, e levaram à concentração das atividades produtivas em pontos estratégicos do território nortemineiro, tendo, como exemplo, as indústrias.

A região norte de Minas Gerais é constituída por 89 municípios, dos quais somente cinco concentram as atividades industriais, inclusive do setor siderúrgicometalúrgico: Montes Claros, Pirapora, Várzea da Palma, Capitão Enéas e Bocaiuva. A expansão do capital privado no norte de Minas Gerais, representado pelas indústrias do setor siderúrgico-metalúrgico, ocorreu nos municípios que dispunham, simultaneamente, das redes de transportes terrestres ferroviários e rodoviários, com a função de promover a interação, a integração e a articulação espacial nas escalas locais, regionais, nacionais e internacionais. Dessa forma, espacialmente, as indústrias localizadas em Montes Claros e em Capitão Enéas são acessadas e/ou estão interligadas às demais regiões do país pelas BR 135, 122, 365 e 251, e Ferrovia Centro-Atlântica - FCA. As cidades de Pirapora e Várzea da Palma são ligadas aos mercados pelas BR 365, 496 e 135, e FCA; Bocaiuva possui acesso pela BR 135 e pela FCA (Figura 1).

Nas atividades industriais, o setor siderúrgico-metalúrgico é controlado pela iniciativa privada, sendo estimulado também pelas ações estatais através dos investimentos em infraestrutura econômica, dos incentivos fiscais e financeiros que são disponibilizados pelas instituições públicas federais, como a SUDENE e o Banco do Nordeste do Brasil - BNB. Além disso, os municípios da região norte-mineira subsidiam a atividade industrial doando terrenos e concedendo isenções de tributos municipais. Tudo isso, somado também ao baixo custo da mão-de-obra regional, 
torna-se atrativo importante para a instalação de indústrias (PEREIRA, 2010). Nesse processo, o setor siderúrgico-metalúrgico desenvolveu as suas bases produtivas, tornando-se um dos setores econômicos da atividade industrial mais importantes na região norte de Minas Gerais.

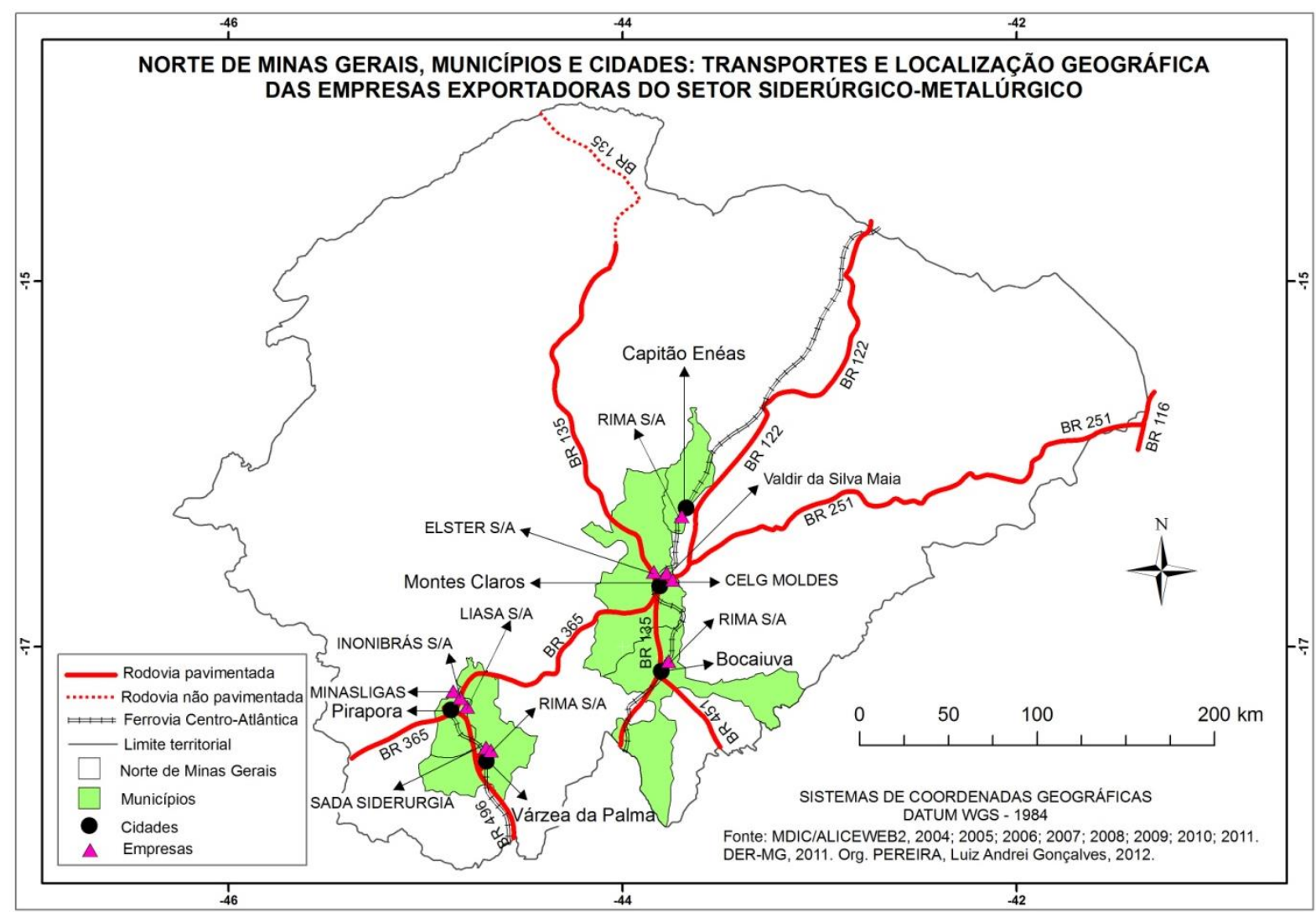

Figura 1 - Norte de Minas Gerais, municípios e cidades: transportes e localização geográfica das empresas exportadoras do setor siderúrgico-metalúrgico. Fonte: MDIC/ALICEWEB2, 2004-2011. Departamento de Estradas de Rodagem de Minas Gerais DER/MG, 2011. Org. PEREIRA, Luiz Andrei Gonçalves, 2012.

Considerando os fluxos das exportações, no período de 2004 a 2008, a região norte-mineira apresentou um crescimento constante nas exportações totais, saindo de 254 para 545 milhões de dólares. Em 2009, ocorreu uma redução dos fluxos das mercadorias de 545 para 445 milhões de dólares; provavelmente, isso ocorreu devido à crise econômica internacional. A partir de 2010, os fluxos das exportações voltaram a crescer de forma mais acelerada, saltando de 445 para 702, em 2010, e chegando a 966 milhões de dólares, em 2011. Por sua vez, as exportações do setor siderúrgico-metalúrgico apresentaram um crescimento de 2004 para 2005, saltando 
de 167 para 204 milhões de dólares; porém, em 2006, apresentou uma leve queda, de 204 para 196 milhões de dólares. No período que decorre de 2007 a 2008, voltou à dinâmica de crescimento, passando de 196 para 351 milhões de dólares. Enquanto em 2009 apresentou novamente uma queda mais acentuada, indo de 351 para 228 milhões de dólares, que pode ser justificada também pela crise mundial; porém, em 2010, voltou a crescer de forma mais acentuada, saltando de 228 para 371; e, em 2011, chegou a 508 milhões de dólares (vide Gráfico 1).

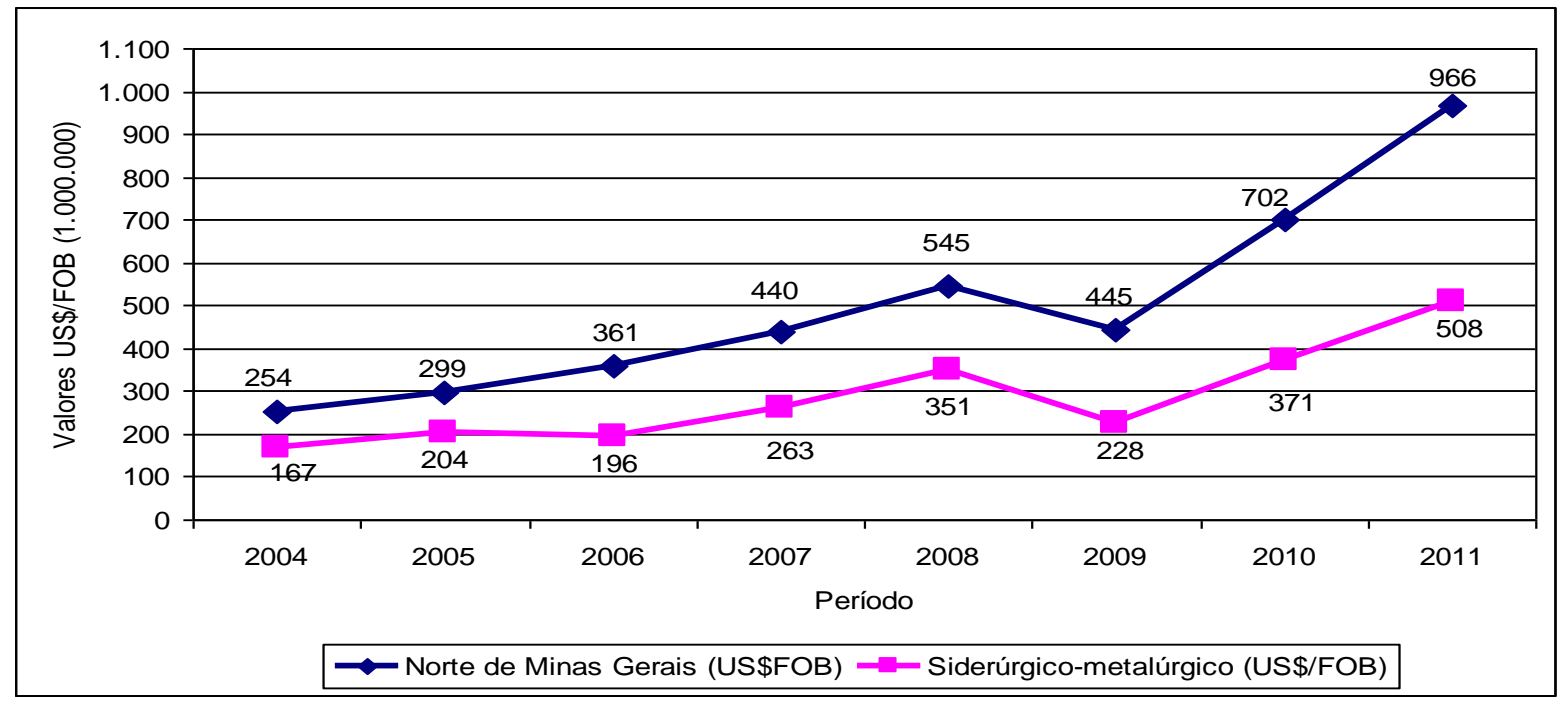

Gráfico 1 - Exportações da região norte de Minas Gerais e do setor siderúrgico-metalúrgico, no período de 2004 a 2011 (USS/FOB - 1.000.000 - moeda corrente). Fonte: MDIC/ALICEWEB2, 2004; 2005; 2006; 2007; 2008; 2009; 2010; 2011. Org. PEREIRA, Luiz Andrei Gonçalves, 2012.

Depois da análise dos fluxos financeiros das mercadorias vendidas ao exterior, destaca-se a circulação de quantidade em toneladas das mercadorias exportadas pela região norte de Minas Gerais. De 2004 a 2007, ocorreu um pequeno crescimento nas exportações, que foi de 169 para 186 mil toneladas, estagnando-se em 2006; isto se comparado a 2005. No período entre 2008 e 2009, ocorreu uma queda mais acentuada, apresentando um decréscimo - de 186 (em 2007) para 159 e 113 mil toneladas, respectivamente -, tendo como possível causa a crise econômica internacional. De 2010 a 2011, houve um crescimento mais acentuado, saltando de 113 (em 2009) para 176 e 246 mil toneladas, respectivamente. O setor siderúrgico-metalúrgico apresentou também características semelhantes às exportações totais da região norte-mineira: no período de 2004 a 2007, houve um leve crescimento, saindo de 138 para 156 mil toneladas, estagnando-se em 2006, 
quando se compara com 2005. Entre o ano de 2008 e 2009, apresentou decréscimo - de 156 (em 2007) para 133 e 104 mil toneladas -, possivelmente por causa da crise mundial. Em 2010, apresentou um crescimento acentuado, indo de 104 (em 2009) para 166 mil toneladas; em 2011, voltou a ter um leve crescimento, indo de 166 para 172 mil toneladas (Vide Gráfico 2).

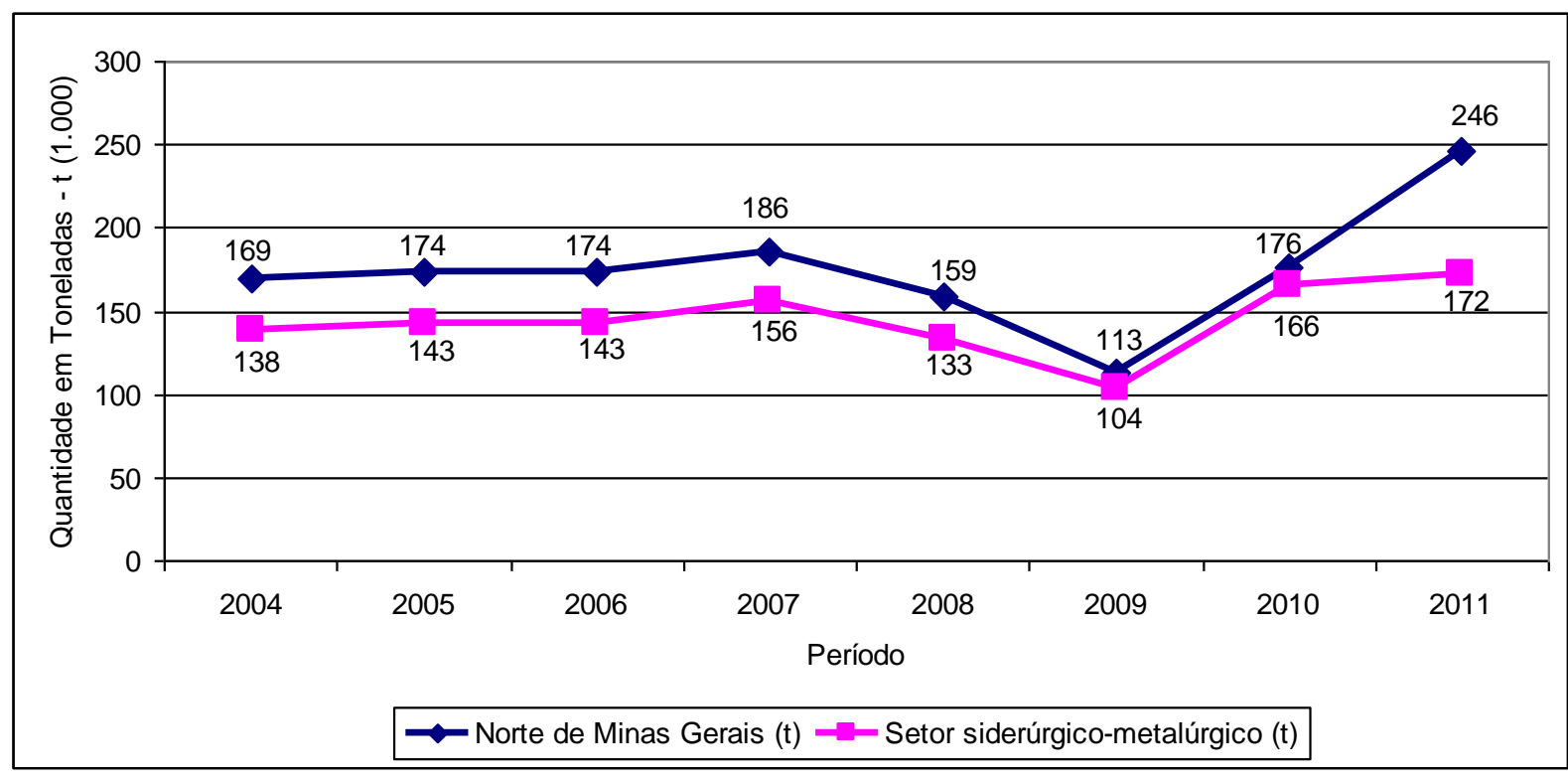

Gráfico 2 - Exportações da região norte de Minas Gerais e do setor siderúrgico-metalúrgico, no período de 2004 a 2011 (Toneladas - $t$ - 1.000). Fonte: MDIC/ALICEWEB2, 2004; 2005; 2006; 2007; 2008; 2009; 2010; 2011. Org. PEREIRA, Luiz Andrei Gonçalves, 2012.

Após a apresentação dos dados estatísticos das exportações na região norte de Minas Gerais, é possível caracterizar a importância do setor siderúrgicometalúrgico na participação dos fluxos de comércio internacional, uma vez que esse setor exportou, em média, no período analisado, cerca de $57 \%$ dos valores em dinheiro e aproximadamente $83 \%$ do peso/volume de cargas exportadas. Nesse contexto, o setor siderúrgico-metalúrgico foi representado por dez empresas exportadoras com domicílios fiscais na região em estudo. Os principais produtos exportados foram: silício, ferrossilício, ferroligas, blocos de motores, peças automotivas, corpos roedores (esferas), placas ferroviárias, contadores de líquidos (hidrômetros), material de precisão, pinos, parafusos e porcas, entre outros. A seção seguinte visa analisar a rede de transportes que promove os fluxos das exportações de mercadorias do setor siderúrgico-metalúrgico no cenário internacional. 


\section{Redes de transportes e fluxos das exportações do setor siderúrgico- metalúrgico no norte de Minas Gerais}

Na política de exportação da região norte-mineira, as redes de transportes foram estruturadas em transporte nacional, terminais alfandegados e transporte internacional. Todas as empresas do setor siderúrgico-metalúrgico utilizaram, no percurso nacional, o transporte rodoviário para o escoamento da produção destinada ao mercado externo, por causa da agilidade da modalidade rodoviária no processo de deslocamento das mercadorias, associada também à falta de um sistema ferroviário adequado para o transporte de produtos siderúrgico-metalúrgicos.

Os fluxos das mercadorias foram direcionados aos terminais alfandegados portuários, aeroportuários e pontos de fronteiras. De forma específica, o porto do Rio de Janeiro (RJ) foi o principal concentrador dos fluxos, recebendo $78,10 \%$ dos fluxos em dinheiro e $82,16 \%$ da quantidade em toneladas. O porto de Sepetiba (RJ) atraiu $13,78 \%$ dos fluxos em dinheiro e $14,68 \%$ da quantidade em toneladas. Em seguida, o porto de Santos (SP) recebeu 1,22\% dos fluxos em dinheiro e menos de $1 \%$ da quantidade em toneladas. Os demais portos receberam, individualmente, fluxos em dinheiro e em toneladas inferiores a $1 \%$. O ponto de fronteira de São Borja (RS) recebeu $5,37 \%$ dos fluxos em dinheiro e 1,75\% da quantidade em toneladas. Os demais pontos de fronteiras receberam, individualmente, fluxos dos valores em dinheiro e em toneladas inferiores a 1\%. Quanto aos aeroportos, estes receberam, individualmente, fluxos dos valores em dinheiro inferiores a $0,5 \%$; e os fluxos em toneladas, inferiores a 0,05\% (Figuras 2 e 3).

Além da distribuição espacial dos fluxos das exportações, a Tabela 1 vem mostrar detalhadamente os valores dos fluxos em dinheiro e da quantidade em toneladas dos produtos do setor siderúrgico-metalúrgico em cada terminal alfandegado utilizado, incluindo também os fluxos por modal de transporte nacional e internacional. 


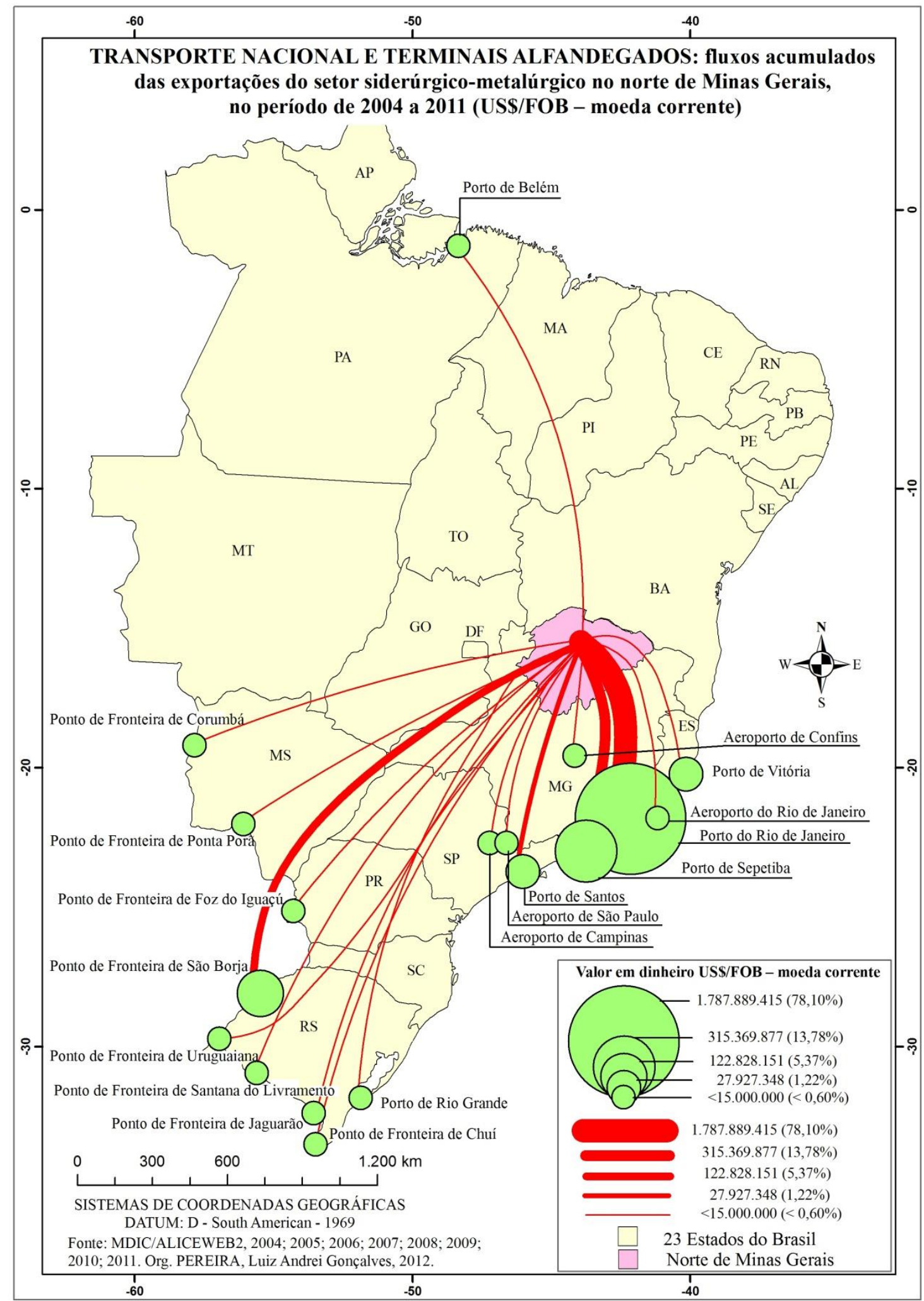

Figura 2 - Transporte nacional e terminais alfandegados: fluxos acumulados das exportações do setor siderúrgico-metalúrgico no norte de Minas Gerais, no período de 2004 a 2011 (US \$/FOB - moeda corrente). Fonte: MEDIC/ALICEWEB2, 2004; 2005; 2006; 2007; 2008; 2009; 2010; 2011. Org. PEREIRA, Luiz Andrei Gonçalves, 2012. 


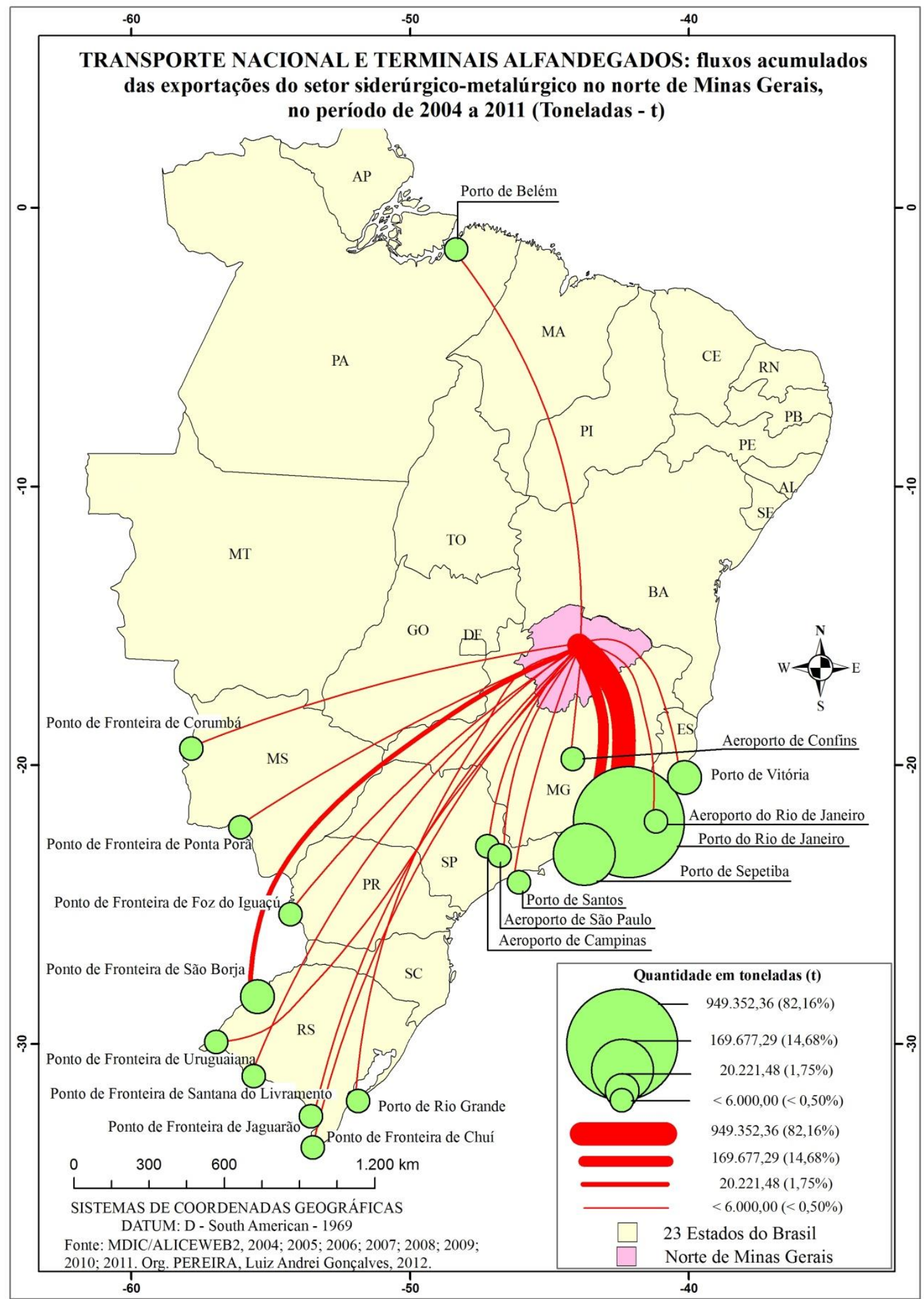

Figura 3 - Transporte nacional e terminais alfandegados: fluxos acumulados das exportações do setor siderúrgico-metalúrgico no norte de Minas Gerais, no período de 2004 a 2011 (Toneladas - t). Fonte: MEDIC/ALICEWEB2, 2004; 2005; 2006; 2007; 2008; 2009; 2010; 2011. Org. PEREIRA, Luiz Andrei Gonçalves, 2012. 
Tabela 1- Fluxos acumulados das exportações do setor siderúrgico-metalúrgico na região norte de Minas Gerais, no período de 2004 a 2011: transporte nacional, terminais alfandegados e transporte internacional de cargas

\begin{tabular}{|c|c|c|c|c|c|c|c|c|}
\hline \multicolumn{3}{|c|}{ Modal de transporte } & \multicolumn{6}{|c|}{ Fluxos das mercadorias exportadas } \\
\hline Nacional & \multicolumn{2}{|c|}{ Internacional } & \multicolumn{2}{|c|}{ Terminais Alfandegados } & $\begin{array}{c}\text { US\$/FOB - } \\
\text { Moeda corrente }\end{array}$ & $\%$ & $\begin{array}{l}\text { Quantidade em } \\
\text { toneladas (t) }\end{array}$ & $\%$ \\
\hline \multirow{6}{*}{ 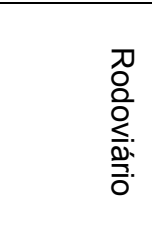 } & \multirow{6}{*}{\multicolumn{2}{|c|}{$\frac{3}{\stackrel{3}{=}}$}} & \multirow{6}{*}{ 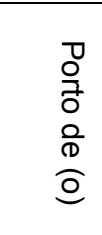 } & Rio de Janeiro (RJ) & 1.787.889.415 & 78,10 & $949.352,36$ & 82,16 \\
\hline & & & & Sepetiba (RJ) & 315.369 .877 & 13,78 & $169.677,29$ & 14,68 \\
\hline & & & & Santos (SP) & 27.927 .348 & 1,22 & $5.112,47$ & 0,44 \\
\hline & & & & Vitória (ES) & 2.427 .303 & 0,11 & $1.979,36$ & 0,17 \\
\hline & & & & Rio Grande (RS) & 2.252 .639 & 0,10 & 920,77 & 0,08 \\
\hline & & & & Belém (PA) & 236.250 & 0,01 & 150,00 & 0,01 \\
\hline \multirow{5}{*}{ 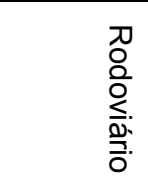 } & \multirow{5}{*}{\multicolumn{2}{|c|}{$\begin{array}{l}\stackrel{\mathbb{\Phi}}{\mathbb{\Phi}} \\
\text { ○ }\end{array}$}} & \multirow{5}{*}{ 응 $\frac{\text { D }}{\frac{D}{0}}$} & Guarulhos (SP) & 7.729 .700 & 0,34 & 428,73 & 0,04 \\
\hline & & & & Campinas (SP) & 3.717 .854 & 0,16 & 243,74 & 0,02 \\
\hline & & & & Rio de Janeiro (RJ) & 236.392 & 0,01 & 16,28 & 0,00 \\
\hline & & & & Confins (MG) & 77.164 & 0,00 & 3,68 & 0,00 \\
\hline & & & & Uruguaiana (RS) & 1.9845 & 0,00 & 6,91 & 0,00 \\
\hline \multirow{8}{*}{ 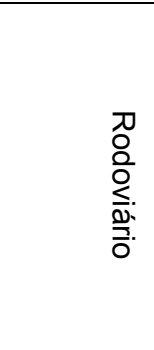 } & \multirow{8}{*}{\multicolumn{2}{|c|}{ 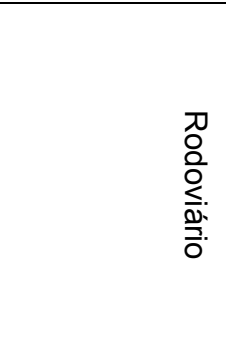 }} & \multirow{8}{*}{ 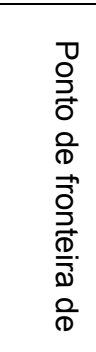 } & São Borja (RS) & 122.828 .151 & 5,37 & $20.221,48$ & 1,75 \\
\hline & & & & Uruguaiana (RS) & 12.790 .656 & 0,56 & $5.096,37$ & 0,45 \\
\hline & & & & Foz do Iguaçu (PR) & 3.266 .268 & 0,14 & $1.384,35$ & 0,12 \\
\hline & & & & \begin{tabular}{|l|} 
Santana do \\
Livramento (RS) \\
\end{tabular} & 1.395 .585 & 0,06 & 86,47 & 0,01 \\
\hline & & & & Chuí (RS) & 1.002 .902 & 0,04 & 863,25 & 0,07 \\
\hline & & & & Jaguarão (RS) & 9.097 & 0,00 & 5,50 & 0,00 \\
\hline & & & & Corumbá (MS) & 13.500 & 0,00 & 0,95 & 0,00 \\
\hline & & & & Pontaporã (MS) & 200 & 0,00 & 0,02 & 0,00 \\
\hline \multicolumn{4}{|c|}{ Norte de Minas Gerais } & Total & 2.289.190.146 & 100 & $1.155 .549,98$ & 100 \\
\hline \multicolumn{9}{|c|}{ Resumo } \\
\hline \multicolumn{4}{|c|}{ Modal de transporte (Geral) } & \multicolumn{5}{|c|}{ Fluxos por terminas alfandegados de cargas (Geral) } \\
\hline \multicolumn{2}{|c|}{ Nacional } & \multicolumn{2}{|c|}{ Internacional } & Terminais & US\$/FOB & $\%$ & Toneladas (t) & $\%$ \\
\hline \multicolumn{2}{|c|}{ Rodoviário } & \multicolumn{2}{|c|}{ Marítimo } & Portos & 2.136 .102 .832 & 93,32 & $1.127 .192,25$ & 97,54 \\
\hline \multicolumn{2}{|c|}{ Rodoviário } & \multicolumn{2}{|c|}{ Aéreo } & Aeroportos & 11.780 .955 & 0,51 & 699,34 & 0,06 \\
\hline \multicolumn{2}{|c|}{ Rodoviário } & \multicolumn{2}{|c|}{ Rodoviário } & Pontos de fronteiras & 141.306 .359 & 6,17 & $27.658,39$ & 2,40 \\
\hline \multicolumn{2}{|l|}{-} & \multicolumn{2}{|l|}{-} & Total & 2.289.190.146 & 100 & $1.155 .549,98$ & 100 \\
\hline
\end{tabular}

Fonte: MDIC/ALICEWEB2, 2004; 2005; 2006; 2007; 2008; 2009; 2010; 2011. Org. PEREIRA, Luiz Andrei Gonçalves, 2012.

A Tabela 1 mostra que, a partir dos fluxos nos terminais alfandegados, é possível afirmar que $93,32 \%$ dos valores em dinheiro e $97,54 \%$ da quantidade em toneladas foram embarcados nos portos e transportados pelo transporte marítimo, por causa dos menores custos operacionais dessa modalidade, principalmente dos fretes, mas também por ser um meio de transporte ideal para o escoamento de grandes quantidades em pesos e volumes por longas distâncias. Através dos pontos de fronteiras, foram embarcados $6,17 \%$ dos fluxos das mercadorias em dinheiro e $2,4 \%$ das cargas em toneladas, que foram conduzidas por transporte rodoviário internacional para os países vizinhos do Brasil, como Argentina, Paraguai, Bolívia, Uruguai e outros. Enquanto isso, os pequenos volumes de cargas que necessitam de urgência na entrega foram embarcados nos aeroportos e enviados por transporte 
aéreo internacional, o equivalente a $0,51 \%$ dos valores em dinheiro e $0,06 \%$ da quantidade em toneladas, pois o transporte aeroviário apresenta um custo operacional mais elevado para o deslocamento de cargas no espaço geográfico. Isso justifica o baixo uso dessa modalidade de transporte.

Nos fluxos das exportações, as empresas localizadas em Pirapora, Várzea da Palma e Capitão Enéas concentraram as embarcações de cargas nos terminais portuários localizados no estado do Rio de Janeiro (porto do Rio de Janeiro e de Sepetiba), pelo fato de estarem localizados geograficamente mais próximos da região norte-mineira e por oferecerem bons serviços na área de logística e de transportes. A empresa localizada em Bocaiuva concentrou seus fluxos no ponto de fronteira de São Borja (RS), pelo fato de grande parte da mercadoria ser exportada para o mercado argentino. As empresas localizadas em Montes Claros concentram os fluxos das mercadorias exportadas no porto de Santos (SP) devido à maior facilidade de enviar cargas para o estado de São Paulo e a melhor infraestrutura de serviços logísticos oferecidos nesse terminal. Em casos mais específicos, os outros terminais (portos, aeroportos e pontos de fronteiras) foram utilizados de acordo com a necessidade do cliente e com a oferta de transporte internacional disponível para os países no exterior.

Após transposição das fronteiras brasileiras, os fluxos das mercadorias, em valores financeiros, foram destinados aos blocos econômicos regionais: União Europeia $^{1}$, NAFTA $^{2}$, APEC $^{3}$ (excluso países do NAFTA), MERCOSUL ${ }^{4}$ e outros. Os fluxos das exportações do setor siderúrgico-metalúrgico da região norte-mineira, $47,33 \%$ dos valores em dinheiro e $50 \%$ da quantidade em toneladas, foram destinados à União Europeia. Com relação ao NAFTA, foram enviados $19,41 \%$ dos valores em dinheiro e $19,28 \%$ da quantidade em toneladas. No caso da APEC, este bloco recebeu $16,26 \%$ dos fluxos em dinheiro e $17,39 \%$ da quantidade em

\footnotetext{
1 União Europeia: composta por 27 países - Alemanha, França, Itália, Bélgica, Holanda, Luxemburgo, Reino Unido, Irlanda, Dinamarca, Grécia, Portugal, Espanha, Finlândia, Suécia, Áustria, Eslovênia, Eslováquia, República Tcheca, Polônia, Chipre, Malta, Estônia, Lituânia, Letônia, Hungria, Romênia e Bulgária.

${ }_{2}$ Acordo de livre comércio da América do Norte - NAFTA. Composto por três países: Estados Unidos, Canadá e México.

${ }^{3}$ Acordo de livre comércio da América do Norte - NAFTA. Composto por três países: Estados Unidos, Canadá e México.

${ }^{4}$ Mercado Comum do Sul - MERCosUL. Composto por quatro países: Brasil, Argentina, Uruguai e Paraguai.
} 
toneladas. Para o MERCOSUL, exportaram-se $10,27 \%$ dos fluxos em dinheiro e $6,13 \%$ da quantidade em toneladas. Finalizando, os outros blocos/países importaram $6,73 \%$ dos valores em dinheiro e $7,2 \%$ da quantidade em toneladas (Figura 4).

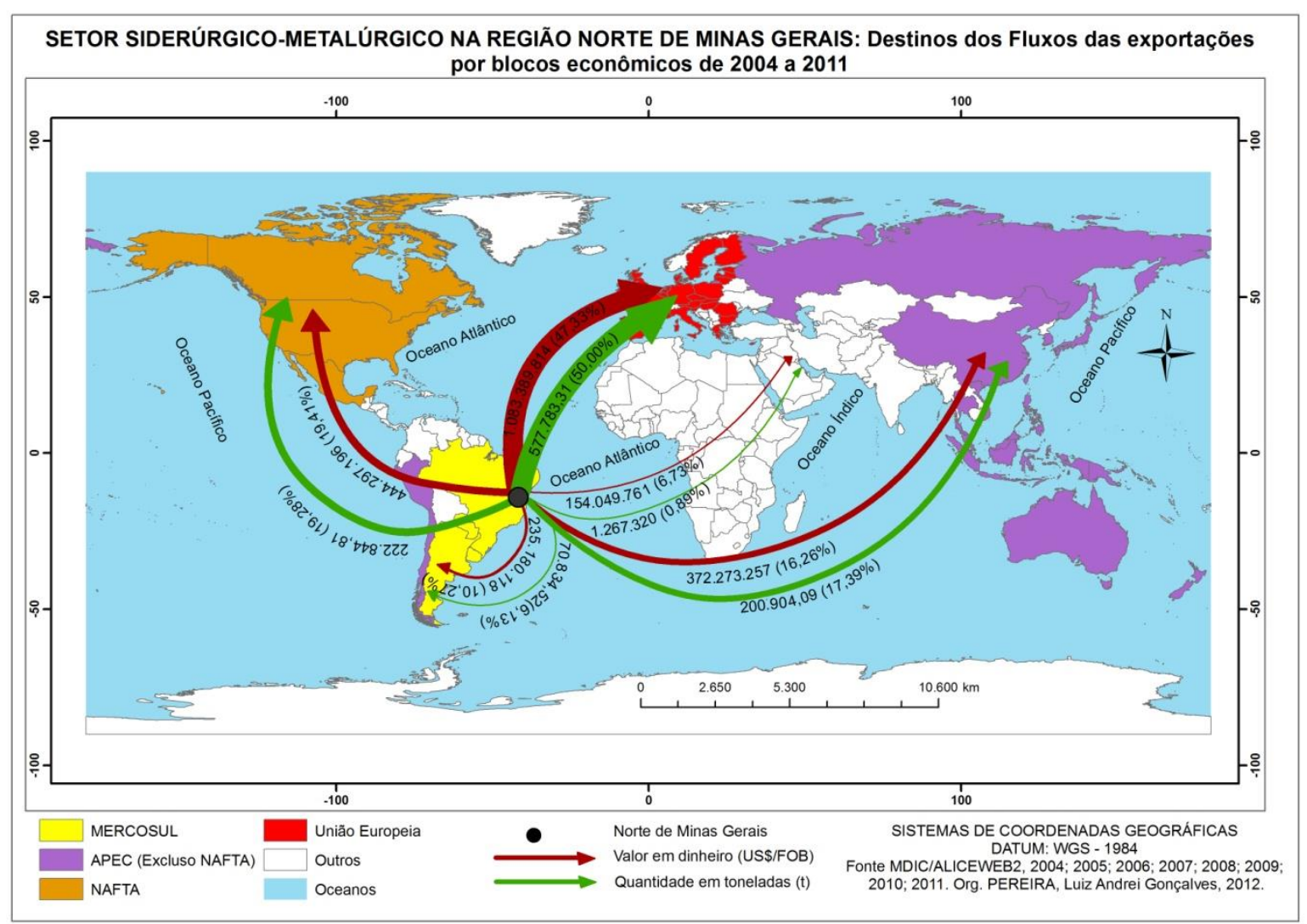

Figura 4 - Setor siderúrgico-metalúrgico na região norte de Minas Gerais: destinos dos fluxos das exportações por blocos econômicos de 2004 a 2011. Fonte: MDIC/ALICEWEB2, 2004; 2005; 2006; 2007; 2008; 2009; 2010; 2011. Org. PEREIRA, Luiz Andrei Gonçalves, 2012.

Nas entrevistas, observamos que todas as empresas do setor siderúrgicometalúrgico, no processo de agilização das exportações, contrataram os prestadores de serviços de transportes fora do norte de Minas Gerais, principalmente na região portuária do Rio de Janeiro e de Santos. Essa escolha é devido à concentração dos profissionais (despachante aduaneiro ${ }^{5}$ ) e das empresas especializadas (operador

\footnotetext{
${ }^{5}$ Despachante aduaneiro - profissional, pessoa física que presta serviços na agilização da documentação necessária ao desembaraço aduaneiro da mercadoria exportada ou importada nas áreas/recintos alfandegados (KEEDI; MENDONÇA, 2000).
} 
logístico ${ }^{6}$ ) nas atividades de prestação de serviços no setor de comércio internacional. É importante ressaltar que as empresas da região norte-mineira também contrataram os serviços de transportes em Sete Lagoas/MG (cidade especializada no setor de siderurgia) para escoar as mercadorias até os terminais alfandegados de cargas. No norte de Minas, a falta de serviços especializados em transportes internacionais estimulou as empresas exportadoras a buscarem esses serviços em outros centros logísticos do Brasil.

Para mercadorias escoadas por transporte marítimo, as empresas contrataram e utilizaram os serviços de aluguel e de estufagem de contêineres de 20 e 40 pés dry cargo (carga seca) nas regiões portuárias. Nas interações espaciais do deslocamento de contêiner, foi possível calcular uma média aproximada dos custos ${ }^{7}$ no percurso nacional das mercadorias contêinerizadas. Os custos nos deslocamentos do contêiner de 40 pés dry cargo na rota entre Pirapora (MG) e Rio de Janeiro (RJ), considerando o contêiner estufado (colocar mercadoria) na base de produção na região norte-mineira, poderiam ser pagos, em média, com aproximadamente US\$3,45 mil dólares ${ }^{8}$ (moeda corrente) por contêiner. Mas as empresas fizeram a opção de levar as mercadorias até as regiões portuárias por meio de carretas; nessas regiões, é feita a estufagem dos contêineres. Isto possibilita uma redução, em torno de 50\%, nos custos de deslocamento de mercadorias no percurso nacional. Dessa forma, os custos do transporte de contêiner estufado nas regiões interioranas tende a serem mais caros, por isso as empresas buscam mecanismos para minimizar esses custos, levando as mercadorias para as regiões portuárias e, nelas, são feitas as contratações e as estufagens dos contêineres.

\footnotetext{
${ }^{6}$ Operador logístico - empresa que presta serviços logísticos, especializada em gerenciar e em executar todas ou parte das atividades logísticas na exportação ou na importação de mercadorias, prestando, simultaneamente, serviços nas atividades de controle de estoque, armazenagem e gestão de transportes (Associação Brasileira de Movimentação e Logística - ABML, 1999).

${ }^{7}$ É importante frisar que essa média dos custos, didaticamente, visa mostrar de forma simples os custos no deslocamento do contêiner em rotas do percurso nacional. O cálculo do custo logístico (armazenagem, transporte e transbordo) é muito mais complexo, pois, especificamente, o custo pode variar de produto para produto, de terminal para terminal e de sentido de deslocamento de rota para rota, uma vez que as tarifas e as taxas sofrem diversas variações de preços.

${ }^{8}$ Dólar = R $\$ 2,03$; cotação do dia 13 de julho de 2012. O contêiner de 40 pés dry cargo estufado em municípios do norte de Minas, por exemplo, Pirapora, tem um custo em torno de $\mathrm{R} \$ 7$ mil reais.
} 
Na política de exportação, o norte de Minas Gerais, como no Brasil, apresenta vários desafios na infraestrutura das redes de transportes, principalmente no setor de transporte nacional e nos terminais alfandegados de cargas. Assim, os principais problemas são: má conservação da infraestrutura da malha rodoviária, infraestrutura precária das ferrovias, burocracia no desembaraço das mercadorias, falta de serviço logístico especializado em comércio internacional na região em estudo, falta de uma Estação Aduaneira Interior - EADI (porto seco) - e deficiências na infraestrutura logística dos terminais alfandegados, principalmente na infraestrutura portuária e aeroportuária.

No Brasil, particularmente no norte de Minas Gerais, os grandes desafios para a superação dos gargalos nas redes de transportes como forma de minimizar os problemas e de maximizar a eficiência e a eficácia das redes de transportes são: programas contínuos de investimentos na melhoria da infraestrutura do sistema rodoviário, investimentos contínuos na modernização do sistema ferroviário, dinamização regional do setor de transportes internacionais, modernização do sistema aduaneiro, instalação de uma Estação Aduaneira Interior - EADI (porto seco) - e programas contínuos de investimentos na modernização na infraestrutura dos terminais alfandegados, principalmente nos portos e aeroportos.

\section{CONSIDERAÇÕES FINAIS}

As redes de transportes promovem a circulação de pessoas, de mercadorias e de serviços no espaço geográfico. Portanto, no comércio internacional, a flexibilidade das redes possibilitou vender e/ou adquirir produtos em diferentes escalas geográficas. Consequentemente, as atividades econômicas comerciais estão mais dependentes da infraestrutura e dos fluxos das redes de transportes, que atuam articuladas com canais de comunicações e de informações, ou vice-versa. $A$ infraestrutura das redes de transportes tem seus reflexos no ordenamento espacial das atividades econômicas na mesorregião norte de Minas Gerais, uma vez que é observada uma concentração das atividades econômicas nos pontos dinâmicos e estratégicos no território norte-mineiro, principalmente naquelas áreas de mais fácil conexão com o mercado nacional e internacional. O processo de modernização 
econômica foi influenciado pelos incentivos fiscais e financeiros, que também favoreceram a expansão das atividades industriais do setor siderúrgico-metalúrgico na região norte-mineira, em Montes Claros, Pirapora, Várzea da Palma, Bocaiuva e Capitão Enéas.

As empresas do setor siderúrgico-metalúrgico, no período de 2004 a 2011, tiveram uma participação importante nas exportações da região norte de Minas Gerais, exportando cerca de US\$2,3 bilhões de dólares (moeda corrente) e aproximadamente 1,2 milhões de toneladas em mercadorias. Todas elas usaram somente o transporte rodoviário para levar as mercadorias do local de produção até os terminais alfandegados de cargas. Na política de exportação, os portos concentraram $93,32 \%$ dos valores em dinheiro e $97,54 \%$ da quantidade em toneladas dos fluxos das mercadorias exportadas. Os pontos de fronteiras escoaram $6,17 \%$ dos fluxos em dinheiro e $2,40 \%$ da quantidade em toneladas; já os terminais aeroportuários receberam $0,51 \%$ dos fluxos em dinheiro e $0,06 \%$ da quantidade em toneladas das exportações.

Considerando os fluxos das exportações por terminais alfandegados, observa-se que o porto do Rio de Janeiro (RJ) foi o maior concentrador dos fluxos das mercadorias, recebendo $78,10 \%$ dos fluxos em dinheiro e $82,16 \%$ da quantidade em toneladas. O porto de Sepetiba (RJ) recebeu $13,78 \%$ dos fluxos em dinheiro e $14,68 \%$ da quantidade em toneladas, seguido pelo ponto de fronteira de São Borja (RS), que atraiu 5,37\% dos fluxos dos valores em dinheiro e 1,75\% da quantidade em toneladas. Logo após, o porto de Santos (SP) recebeu 1,22\% dos fluxos financeiros e menos de $1 \%$ da quantidade em toneladas. Os demais terminais receberam, individualmente, fluxos em dinheiro e em toneladas inferiores a $1 \%$.

As empresas exportadoras do setor siderúrgico-metalúrgico situadas no norte de Minas Gerais contrataram os serviços especializados de transporte internacional, principalmente nas regiões portuárias, que estão associados à utilização elevada dos terminais portuários e de transporte marítimo internacional para os fluxos de mercadorias. A contratação dos serviços especializados de logística - estufagem de contêineres - nas regiões portuárias reduz os custos em aproximadamente $50 \%$ nos fluxos da mercadoria no percurso nacional, ou seja, o fluxo da mercadoria do local de produção até a região portuária. 
Além disso, os gargalos das redes de transportes no Brasil e no norte de Minas Gerais precisam ser minimizados, em curto prazo, e solucionados, em médio e longo prazo, para que as empresas possam ser mais competitivas no cenário internacional. Para que isso ocorra, são necessários programas contínuos de investimentos, visando a melhorias na infraestrutura de transporte rodoviário, ferroviário, dutoviário, hidroviário, aeroviário e marítimo, responsáveis pelas articulações dos fluxos de bens e de serviços no mercado interno e externo.

AGRADECIMENTOS: Apoio financeiro: CAPES (bolsa de estudos).

\section{REFERÊNCIAS}

ARROYO, M. A espacialidade do futuro ... Além das fronteiras nacionais?. Ensaios FEE, Porto Alegre, v. 16, n. 2, p. 491-509, 1995.

Circuitos espaciais de produção industrial e fluxos internacionais de mercadorias na dinâmica territorial do estado de São Paulo. Boletim Campineiro de Geografia, Campinas, v.2, n. 1, p. 7-26, 2012.

ASSOCIAÇÃO BRASILEIRA DE MOVIMENTAÇÃO E LOGÍSTICA - ABML. O conceito de operador logístico. São Paulo: ABML, 1999. Disponível em: <www.abml.org.br>. Acesso em: 20 nov. 2009.

CORRÊA, R. L. Interações espaciais. In: Castro, I. E.; GOMES, P. C. C.; CORRÊA, R. L. (Org.). Explorações geográficas. 2. ed. Rio de Janeiro: Bertrand Brasil, 2006. 368 p. p. $279-318$.

DEPARTAMENTO DE ESTRADAS DE RODOGEM DE MINAS GERAIS - DER/MG. Mapa rodoviário do Estado de Minas Gerais. Belo Horizonte: DER/MG, 2011. Mapa rodoviário. Escala 1: 1.500.000.

HOYLE, B. KNOWLES, R. (Org.). Modern transport geography. 2. ed. ChichesterUK: John Wiley \& Sons Ltd, 2001. 374 p.

KEEDI, S. MENDONÇA, P. C. C. Transportes e seguros no comércio exterior. São Paulo: Aduaneiras, 2000. 251 p.

LAXE, F. G. Puertos y transporte marítimo: ejes de una nueva articulación globaL. In: Revista de Economia Mundial, n. 12, p. 123-148, 2005. 
MAIA, J. M. Economia internacional e comércio exterior. São Paulo: Atlas, 2004. $430 \mathrm{p}$.

MINISTÉRIO DO DESENVOLVIMENTO INDÚSTRIA E COMÉRCIO EXTERIOR MDIC/ALICEWEB2. Exportação municípios. Brasília: MDIC, 2004. Disponível em $<$ http://aliceweb2.mdic.gov.br/>. Acesso em: 10 jan. 2012.

Exportação municípios. Brasília: MDIC, 2005. Disponível em <http://aliceweb2.mdic.gov.br/>. Acesso em: 10 jan. 2012.

Exportação municípios. Brasília: MDIC, 2006. Disponível em <http://aliceweb2.mdic.gov.br/>. Acesso em: 10 jan. 2012.

Exportação municípios. Brasília: MDIC, 2007. Disponível em <http://aliceweb2.mdic.gov.br/>. Acesso em: 10 jan. 2012.

Exportação municípios. Brasília: MDIC, 2008. Disponível em $<$ http://aliceweb2.mdic.gov.br/>. Acesso em: 10 jan. 2012.

Exportação municípios. Brasília: MDIC, 2009. Disponível em <http://aliceweb2.mdic.gov.br/>. Acesso em: 10 jan. 2012.

Exportação municípios. Brasília: MDIC, 2010. Disponível em <http://aliceweb2.mdic.gov.br/>. Acesso em: 10 jan. 2012.

Exportação municípios. Brasília: MDIC, 2011. Disponível em <http://aliceweb2.mdic.gov.br/>. Acesso em: 10 jan. 2012.

MONIÉ, Frédéric. Planejamento territorial, modernização portuária e logística: o impasse das políticas públicas no Brasil e no Rio de Janeiro. In: MONIÉ, Frédéric; Silva, Geraldo (Org.). A mobilização produtiva dos territórios: instituições e logística do desenvolvimento local. Rio de Janeiro: DP\&A, 2003. 144 p. p. 57-80.

MONIÉ, Frédéric. Globalização, modernização do sistema portuário e relações cidade-porto no Brasil. In: SILVEIRA, Márcio Rogério (Org.). Circulação, transportes e logística: diferentes perspectivas. São Paulo: Outras Expressões, 2011. 624 p. p. 299-330.

PEREIRA, L. A. G. Planejamento e Desenvolvimento: Logística de transportes e exportações na mesorregião norte de Minas Gerais. 2010. 174 f. Dissertação (Mestrado em Desenvolvimento Social) - Programa de Pós-Graduação em Desenvolvimento Social, Universidade Estadual de Montes Claros - UNIMONTES, Montes Claros, 2010.

PEREIRA, L. A. G. LESSA, S. N. Processo de planejamento e desenvolvimento da logística de transportes. Revista Mercator, Fortaleza, v. 10, n. 22, p. 37-56, 2011. 
PEYRELONGUE, C. M. El puerto y la vinculación entre lo local y lo global. Revista Eure, Santiago, v. 25, n. 75, p. 103-120, 1999.

PONS, J. M. S. BEY, J. M. P. Geografía de redes y sistemas de transporte. Madrid: Editorial Síntesis, 1991. 231 p.

PONS, J. M. S.; REYNÉS, M. R. M. Geografia de los transportes. Palma de Mallorca: Universitat de les illes Balears, 2004. 444 p.

RODRIGUE, J.; COMTOIS, C.; SLACK, B. The geography of transport systems. 2 ed. Abingdon, Oxon, England; New York: Routledge, 2006. 352 p.

RODRIGUE, J. Globalization and the Synchronization of Transport Terminals. In: Journal of Transport Geography, v. 7, n. 4, p. 255-261, 1999.

RODRIGUE, J. NOTTEBOOM, T. The Geography of Containerization: Half a Century of Revolution, Adaptation and Diffusion. In: GeoJournal, v. 74, n. 1, p. 1-5, 2009.

TAAFFE, E. J.; GAUTHIER, H. L.; O`KELLY, M. E. Geography of transportation. 2 ed. New Jersey: Prentice-Hall, 1996. 422 p. 